\title{
Catalytic oxidation of Cedar Bark (Pinus Sibirica) with Oxygen to Vanillin and Pulp
}

\author{
Dmitry O. Vigul, Valery E. Tarabanko*, \\ Yulia V. Chelbina and Vladimir A. Levdansky \\ Institute of Chemistry and Chemical Technology SB RAS \\ $F R C$ «Krasnoyarsk Scientific Center of the SB RAS» \\ Krasnoyarsk, Russian Federation
}

Received 06.09.2021, received in revised form 22.09.2021, accepted 25.10.2021

\begin{abstract}
The catalytic oxidation of natural and pre-extracted cedar bark (Pinus Sibirica) by molecular oxygen is studied. Tannins were shown to inhibit the formation of vanillin while oxidizing the bark. The yields of vanillin are 5-7 wt.\% based on bark lignin, which is of 3-4 times lower compared to the results of wood oxidation. The presence of tannins in the raw material complicates the lignin analysis and can overestimate the results twice.
\end{abstract}

Keywords: catalytic oxidation, cedar bark, pinus sibirica, lignin, vanillin, acetovanillone, vanillic acid, pulp, tannins.

Acknowledgments. This work was conducted within the framework of the budget project № 0287-20210017 for Institute of Chemistry and Chemical Technology SB RAS using the equipment of Krasnoyarsk Regional Research Equipment Centre of SB RAS.

Citation: Vigul, D. O., Tarabanko, V.E., Chelbina, Yu.V., Levdansky, V. A. Catalytic oxidation of cedar bark (Pinus Sibirica) with oxygen to vanillin and pulp, J. Sib. Fed. Univ. Chem., 2021, 14(4), 457-463. DOI: 10.17516/1998-2836-0254

(C) Siberian Federal University. All rights reserved

This work is licensed under a Creative Commons Attribution-NonCommercial 4.0 International License (CC BY-NC 4.0).

* Corresponding author E-mail address: veta@icct.ru 


\title{
Каталитическое окисление коры кедра (Pinus Sibirica) кислородом в ванилин и целлюлозу
}

\author{
Д. О. Вигуль, В.Е. Тарабанько, \\ Ю. В. Челбина, В. А. Левданский \\ Институт химии и химической технологии СО РАН \\ ФИЦ «Красноярский научный центтр СО РАН» \\ Российская Федеращия, Красноярск
}

\begin{abstract}
Аннотация. Изучен процесс каталитического окисления образцов натуральной и предварительно проэкстрагированной коры кедра сибирского (Pinus Sibirica) молекулярным кислородом. Показано, что таннины ингибируют образование ванилина при окислении коры. Выход ванилина составляет 5-7 мас.\% в пересчете на лигнин коры, что в 3-4 раза ниже по сравнению с результатами окисления древесины. Наличие таннинов в сырье усложняет анализ лигнина и завышает результаты более чем в два раза.
\end{abstract}

Ключевые слова: каталитическое окисление, кора кедра, сосна сибирская, лигнин, ванилин, ацетованиллон, ванилиновая кислота, целлюлоза, таннины.

Благодарности. Работа проведена в рамках бюджетного проекта № 0287-2021-0017 для Института химии и химической технологии СО РАН с использованием оборудования Красноярского регионального научно-исследовательского центра СО РАН.

Цитирование: Цитирование: Вигуль, Д. О. Каталитическое окисление коры кедра (Pinus Sibirica) кислородом в ванилин и целлюлозу / Д. О. Вигуль, В.Е. Тарабанько, Ю. В. Челбина, В. А. Левданский // Журн. Сиб. федер. ун-та. Химия, 2021, 14(4). C. 457-463. DOI: 10.17516/1998-2836-0254

\section{Introduction}

Catalytic oxidation of native wood lignins with oxygen gives significant yields of aromatic aldehydes. Recently, there has been an increasing interest in the integrated use and deep processing of wood and also bark as well, due to the large amount of industrial wastes (up to $15 \%$ of the processed wood) [1].

The cedar bark (PinusSibirica) is a complex of tissues formed from the cambium in the form of two layers: a bast - the inner layer which adjacent to the cambium, and the outer layer - the crust. The bast conducts organic nutrients formed in the leaves down the trunk, the outer crust protects the trunk tissues from mechanical damage, the penetration of fungi and bacteria, a sharp change in temperature and moisture evaporation.

The chemical composition of the bark and wood are different. The bark contains significantly less cellulose than wood, and according to the literature data, the content of lignin in the bark is higher than in the stem part, and reaches $32 \mathrm{wt} . \%$ [2,3]. For this reason, the bark could be a very convenient raw material for vanillin production. 
The possibility of catalytic oxidation of birch bast into syringaldehyde, vanillin and the corresponding acetyl derivatives was demonstrated earlier [4]. The oxidation of cedar bark into aromatic aldehydes is not described in the literature. The catalytic oxidation process of natural and pre-extracted cedar bark (PinusSibirica) with oxygen is studied in this paper.

\section{Experimental}

Samples of natural Siberian cedar (PinusSibirica) bark were used, as well as samples preextracted with $\mathrm{H}_{2} \mathrm{O}$ (boiling in water; bark, $100 \mathrm{~g}$; water, $1500 \mathrm{ml}$; duration, 1 hour; weight loss, 11.0 wt.\%) and EtOH (extraction in the Soxlett apparatus; EtOH, 2000 ml; duration, 120 hours; weight loss, 16.7 wt.\%). Alkaline treatment of the bark $(5 \mathrm{~g})$ was carried out with $1 \% \mathrm{NaOH}$ solution $(250 \mathrm{ml})$ for one hour while boiling. The lignin content in the samples was determined by the mass of the solid residue after hydrolysis of the samples with $72 \%$ sulfuric acid (the Kürschner method) [5].

The calculated lignin content in the samples of the initial and pre-extracted bark was determined by the formula

$$
\mathrm{L}_{\text {calc. }}=\frac{\mathrm{L}_{\mathrm{NaOH}} \cdot\left(1-\mathrm{W}_{\text {loss } \mathrm{NaOH}} / 100 \%\right)}{1-\mathrm{W}_{\text {loss extr }} / 100 \%}
$$

where $\mathrm{L}_{\text {calc }}$ - calculated lignin content in the samples, $\mathrm{L}_{\mathrm{NaOH}}-$ the lignin content in the bark sample after its sequential extraction with ethanol and alkali, $\mathrm{W}_{\text {lossNaOH }}$ - weight loss of the bark sample after extraction with ethanol and alkali, $\mathrm{W}_{\text {lossextr }}$ - bark weight loss after extraction with water or ethanol. Lignin content in the sample of the initial bark was calculated by the formula (1) at $\mathrm{W}_{\text {lossextr }}=0$.

The reaction mass was prepared by sequential mixing the catalyst $\left(\mathrm{CuSO}_{4} \times 5 \mathrm{H}_{2} \mathrm{O}\right)$, alkali, water and bark. Experiments were conducted in a stainless steel autoclave (volume, $1 \mathrm{~L}$; inner diameter, $85 \mathrm{~mm}$; height, $180 \mathrm{~mm}$ ) at $160^{\circ} \mathrm{C}$ and oxygen partial pressure $0.2 \mathrm{MPa}$. Before heating, the reactor was purged with argon, heating was also carried out in an argon atmosphere. Stirring was done with a magnetic stirrer (stir bar diameter, $10 \mathrm{~mm}$; length, $60 \mathrm{~mm}$; stirring speed, $700 \mathrm{rpm}$ ). Duration of heating (under argon) and stabilization of the temperature was $25-40 \mathrm{~min}$, the process duration at a given temperature is 60 minutes. Oxygen was fed into the reactor from a calibrated buffer volume through a valve, maintaining constant pressure in the reactor. Amount of the consumed oxygen was calculated from pressure change inside the buffer volume.Temperature was maintained automatically with $\pm 2{ }^{\circ} \mathrm{C}$ precision.

Samples of the reaction mass with a volume of $13-15 \mathrm{ml}$ were taken at regular intervals, adjusted with $1 \mathrm{M} \mathrm{HCl}$ solution to $\mathrm{pH} \mathrm{3-4,} \mathrm{and} \mathrm{exhaustively} \mathrm{extracted} \mathrm{with} \mathrm{chloroform.}$

Concentration of components was determined by GLC (Chromos Engineering GH1000 chromatograph, column $30 \mathrm{~m} \times 0.32 \mathrm{~mm}$, stationary phase phenylpolysiloxane, $5 \%$ ), column temperature $170{ }^{\circ} \mathrm{C}$, anthracene was used as internal standard.

\section{Results and discussion}

\section{Lignin content in cedar bark}

Table 1 shows the analysis results for the content of cellulose and lignin in the samples of the initial and pre-extracted bark. The analysis of wood bark (unlike wood) for lignin by the sulfuric acid method can give overestimated results, since the bark, in particular cedar bark, has a high content of

$$
-459-
$$


Table 1. Lignin and cellulose content in cedar bark samples

\begin{tabular}{lcccc}
\hline & $\begin{array}{c}\text { Weight loss after } \\
\text { extraction, wt. } \%\end{array}$ & Lignin, wt.\% & $\begin{array}{c}\text { Cellulose, } \\
\text { wt.\% }\end{array}$ \\
\cline { 2 - 4 } Original cedar bark & - & Analyzed & Calculated & 25.8 \\
\cline { 3 - 4 } Cedar bark extracted with $\mathrm{H}_{2} \mathrm{O}$ & 11.0 & 48.6 & 17.9 & 33.2 \\
Cedar bark extracted with EtOH & 16.7 & 50.8 & 20.1 & 33.0 \\
Cedar bark extracted with EtOH and & 52.7 & 34.8 & 21.5 & - \\
$\mathrm{NaOH}$ & & 37.9 & - & - \\
\hline
\end{tabular}

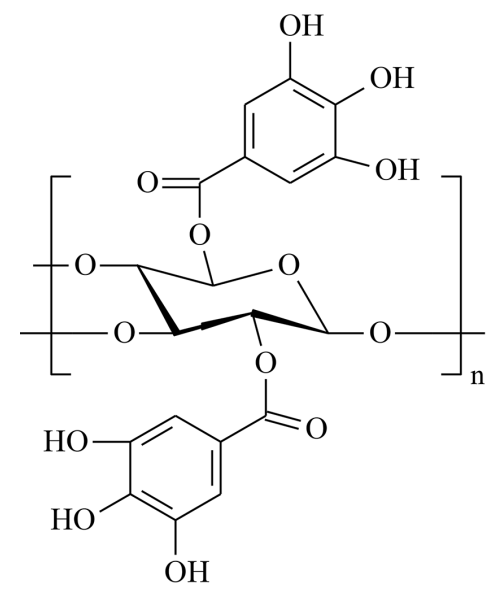

Fig. 1. Hydrolysable tannins are esters of sugars and phenylcarboxylic acids

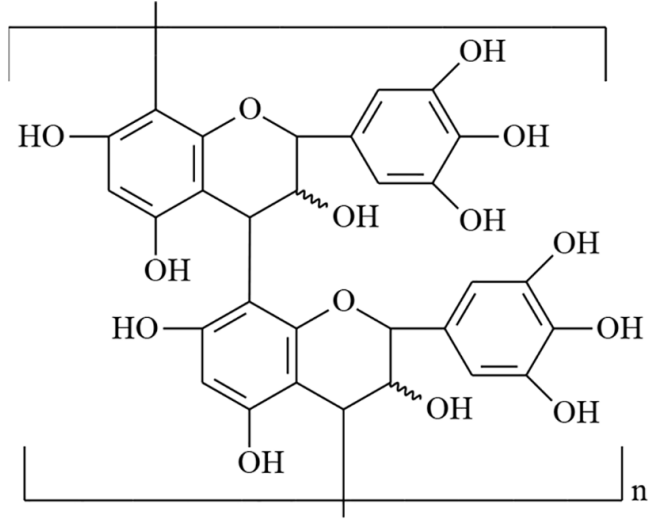

Fig. 2. Condensed tannins are derivatives of flavanols and flavandiols

hydrolyzable (Fig. 1) and condensed (Fig. 2) tannins. Some of these substances are not extracted by organic solvents, and during acid treatment may undergo further condensation and overestimate the results of lignin determination by the traditional method [5].

To extract polyphenolic acids and flavonoids, alcohol extraction of raw materials was carried out, then treated with $1 \%$ alkali solution [5]. The total weight loss after EtOH extraction and alkaline treatment reached $53 \mathrm{wt} . \%$, and the lignin content in this sample was $38 \mathrm{wt} . \%$. Assuming that extraction with an aqueous solution of alkali completely removes tannins from the solid residue, the lignin content in the samples of the initial and extracted bark can be calculated using the formula (1). As tannins were extracted, the lignin content increased from $18 \mathrm{wt} . \%$ in the original bark to $20-22 \mathrm{wt} . \%$ (Table 1).

Thus, the results obtained confirm the well-known recommendations [5] for the lignin determination in the tree bark after the removal of tannins from it, and this ensures the correctness of the data obtained earlier [6-11]. After taking into account the amount of tannins, the lignin content in the cedar bark was reduced by more than two times compared to the direct determination by Kürschner method and amounted about $18 \%$. 


\section{Oxidation of cedar bark samples}

Figures 3-5 show the accumulation curves of carbonyl compounds during the oxidation of the original and pre-extracted samples of cedar bark. The maximum concentrations of vanillin and its yields per loaded substrate were recorded at 30-50 minutes of oxidation and varied in a narrow range of $1.1-1.6 \mathrm{wt} . \%$.

Induction periods of 10-30 minutes should be noted on the accumulation curves of vanillin and other products. Induction periods are not usually observed in the processes of lignins oxidation into aromatic aldehydes [12]. However, inhibiting the oxidation of coniferous wood by syringaldehyde leads to a pronounced induction period on the vanillin accumulation curves and a two-fold decrease in its maximum concentration [13].

Table 2 presents data on the maximum yields of oxidation products based on lignin determined by Kürschner's method, and calculated according to formula (1) (see Table 1).

The maximum yields of vanillin per bark lignin were 6-8 wt.\%, which is 3-4 times lower compared to the yields of vanillin obtained by oxidation of coniferous wood samples [12-14].

The obtained results indicate that during the oxidation of bark samples, the tannins as antioxidants decrease the product yields and form an induction period on their accumulation curves. For these reasons, the coniferous species bark is less suitable for obtaining vanillin compared to wood.

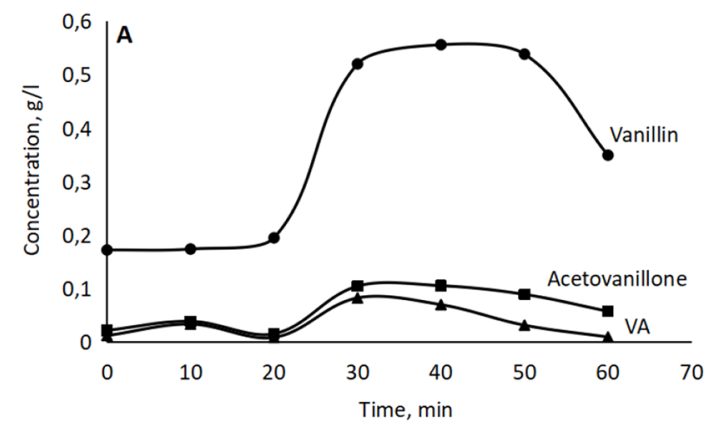

Fig. 3. Accumulation curves of carbonyl compounds and vanillic acid (VA) in the catalytic oxidation process of original cedar bark. Process conditions: $160{ }^{\circ} \mathrm{C}$; bark, $50 \mathrm{~g} / 1 ; \mathrm{NaOH}, 50 \mathrm{~g} / \mathrm{l} ; \mathrm{Cu}(\mathrm{OH})_{2}, 37,5 \mathrm{~g} / 1$; $\mathrm{O}_{2}, 0,2 \mathrm{MPa}$

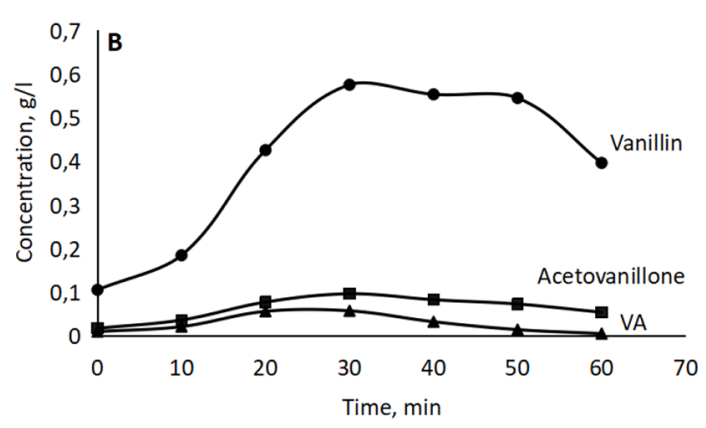

Fig. 4. Accumulation curves of carbonyl compounds and VA in the catalytic oxidation process of cedar bark sample pre-extracted with EtOH. For the process conditions see Fig. 3

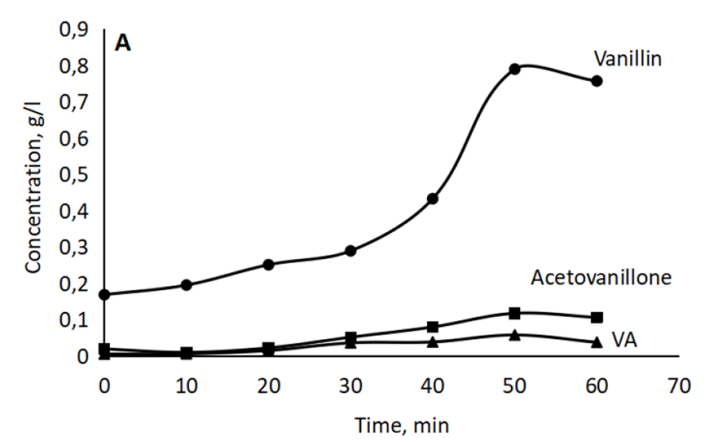

Fig. 5. Accumulation curves of carbonyl compounds and VA in the catalytic oxidation process of cedar bark sample pre-extracted with $\mathrm{H}_{2} \mathrm{O}$. For the process conditions see Fig. 3 
Table 2. Maximum products yields of the initial and pre-extracted cedar bark samples oxidation

\begin{tabular}{lcccccc}
\hline \multirow{2}{*}{ Extractant } & \multicolumn{4}{c}{ Yields of products, wt. \%, based on } \\
\cline { 2 - 7 } & \multicolumn{2}{c}{ Vanillin on } & \multicolumn{2}{c}{ Acetovanillone } & \multicolumn{2}{c}{ Vanillic acid on } \\
& $\begin{array}{c}\text { Lignin }+ \\
\text { Tannins }\end{array}$ & $\begin{array}{c}\text { Lignin } \\
\text { calculated }\end{array}$ & $\begin{array}{c}\text { Lignin }+ \\
\text { Tannins }\end{array}$ & $\begin{array}{c}\text { Lignin } \\
\text { calculated }\end{array}$ & $\begin{array}{c}\text { Lignin }+ \\
\text { Tannins }\end{array}$ & $\begin{array}{c}\text { Lignin } \\
\text { calculated }\end{array}$ \\
\hline Original bark & 2.29 & 6.21 & 0.43 & 1.18 & 0.28 & 0.78 \\
$\mathrm{H}_{2} \mathrm{O}$ & 3.11 & 7.85 & 0.46 & 1.16 & 0.23 & 0.57 \\
EtOH & 2.57 & 5.35 & 0.43 & 0.90 & 0.26 & 0.54 \\
\hline
\end{tabular}

\section{Conclusion}

Thus, the possibilities of cedar bark catalytic oxidation were studied for the first time. Component analysis of cedar bark showed that the classical analysis for lignin with sulfuric acid gives overestimated results due to the high content of tannins in the raw material. The calculated values of the lignin content in the original and pre-extracted bark samples are of 18-20 wt.\%, and this value is almost three times lower than the results of direct lignin determination by Kürschner method in the bark, and a one third lower than the lignin content in a coniferous wood.

The main products obtained by oxidation of samples of natural Siberian cedar bark and preextracted with water and alcohol were vanillin, acetovanillone and vanillic acid. The maximum yields of vanillin per loaded bark samples were recorded at 30-50 minutes of oxidation and vary in a narrow range of $1.1-1.6 \mathrm{wt} . \%$.

The maximum yields of vanillin per bark lignin were 6-8 wt.\%, and they are of 3-4 times lower compared to the yields from coniferous wood samples [12-14]. The obtained results indicate that during the oxidation of bark samples, the tannins perform the function of antioxidants, and this leads to a decrease in the product yields and appearance of an induction period on the vanillin accumulation curves. For these reasons, the bark of coniferous species is less suitable for obtaining vanillin compared to wood.

\section{References}

1. Боровиков А.М., Уголев Б.Н. Справочник по древесине. М.: Лесная промышленность, 1989. 45 c. [Borovikov A.M., Ugolev B.N. Wood Reference book. Moscow: Forest industry, 1989. 45 p. (In Russ.)]

2. Ярцева Н.А. О химическом составе кедра сибирского. Лесной журнал 1969. № 1, С. 112 116. [Yartseva N. A. About the chemical composition of Siberian cedar. Russian forestry journal 1969. № 1, Р. 112-116. (In Russ.)]

3. Бутылкина А.И., Левданский В.А., Калачева Г.С., Кузнецов Б.Н. Хромато-массспектрометрическое изучение химического состава гексанового экстракта коры кедра. Журнал СФУ. Химия 2008. Т. 4(1), С. 293-300. [Butylkina A. I., Levdansky V. A., Kalacheva G. S., Kuznetsov B. N. Chromato-Mass-Spectrometric Investigation of Chemical Composition of Pinus Sibirica Bark Hexan Extract. Journal of Siberian Federal University. Chemistry 2008. Vol. 4(1), P. 293-300. (In Russ.)] 
4. Коропачинская Н.В., Тарабанько В.Е., Левданский В.А. Каталитическое оксиление березового луба кислородом в сиреневый альдегид и ванилин. Химимя растительного сырья 2004. № 1, C. 27-30. [Koropachinskaya N. V., Tarabanko V.E., Levdanskiy V.A. The catalytic oxidation of birch (Betula pendula Roth.) inner bark by oxygen into syringaldehyde and vanillin. Chemistry of plant raw materials 2004. № 1, P. 27-30. (In Russ.)]

5. Оболенская А.В., Ельницкая 3.П., Леонович А.А. Лабораторные работы по химии древесины и целлюлозы. М.: Экология, 1991.320 с. [Obolenskaya A. V., Elnitskaya Z.P., Leonovich A. A. Laboratory works on chemistry of wood and cellulose. Moscow: Ekologiya, 1991. 320 p. (In Russ.)]

6. Дейнеко И.П., Дейнеко И.В., Белов Л.П. Исследование химического состава коры сосны. Химия растительного сырья 2007. № 1, C. 19-24. [Deyneko I.P., Deyneko I. V., Belov L.P. Investigation of the pine bark chemical composition. Chemistry of plant raw materials 2007. № 1, P. 19-24. (In Russ.)]

7. Левданский В.А., Бутылкина А.И., Иванченко Н.М., Кузнецов Б. Н. Экстрактивная переработка коры ели сибирской в ценные химические продукты. Химия растительного сырья 2011. № 1, C. 93-99. [Levdanskiy V. A., Butylkina A. I., Ivanchenko N. M., Kuznetsov B. N. Extractive processing of Siberian spruce bark into valuable chemical products. Chemistry of plant raw materials 2011. № 1, P. 93-99. (In Russ.)]

8. Fang Huang, Preet M. Singh, Arthur J. Ragauskas. Characterization of Milled Wood Lignin (MWL) in Loblolly Pine Stem Wood, Residue, and Bark. J. Agric. Food Chem. 2011. V. 59, P. 1291012916.

9. Левданский В.А., Кондрасенко А.А., Левданский А.В., Лутошкин М.А. Выделение и изучение проантоцианидинов коры пихты. Журнал СФУ. Химия 2019. Т. 12(4), С. 604-613. [Levdansky V.A., Kondrasenko A. A., Levdansky A. V., Lutoshkin M. A. Isolation and study of abies bark proanthocyanidins. Journal of Siberian Federal University. Chemistry 2019.Vol. 12(4), P. 604613. (In Russ.)]

10. Левданский В.А., Королькова И.В., Левданский А.В., Кузнецов Б.Н. Выделение и изучение проантоцианидинов коры сосны pínus sylvéstris l. Химия растительного сырья 2020. № 4, C. 227-233. [Levdansky V. A., Korolkova I. V., Levdansky A. V., Kuznetsov B. N. Extraction and study of proanthocyanidins of pine bark Pinus Sylvéstris l. Chemistry of plant raw materials 2020. № 4, P. 227-233. (In Russ.)]

11. Neiva D. M., Rencoret J., Marques G., Gutiérrez A., Gominho J., Pereira H., del Rio J. C. Lignin from tree barks: chemical structure and valorization. ChemSusChem 2020. Vol. 13, P. 4537-4547.

12. Tarabanko, V. E., Tarabanko N. Catalytic oxidation of lignins into the aromatic aldehydes: general process trends and development prospects. Int. J. Molecular Sciences 2017.Vol. 18, P. 2421.

13. Tarabanko V.E., Kaygorodov K.L., Vigul D.O., Tarabanko N., Chelbina Yu. V., Smirnova M. A. Influence of acid prehydrolysis on the process of wood oxidation into vanillin and pulp. J. Wood Chem. \& Tech. 2020. Vol. 40(6), P. 421-433.

14. Tarabanko V.E., Kaygorodov K.L., Skiba E.A., Tarabanko N., Chelbina Yu.V., Baybakova O. V., Kuznetsov B. N., Djakovitch N. Processing Pine Wood into Vanillin and Glucose by Sequential Catalytic Oxidation and Enzymatic Hydrolysis. Journal of Wood Chemistry and Technology 2017. Vol. 37 (1), P. 43-51.

$$
-463-
$$

